\title{
PKM MODEL PEMBELAJARAN DI PONDOK PESANTREN AN-NAHL DARUNNAJAH 5 CIKEUSIK
}

\author{
Arfatin Nurrahmah ${ }^{1 *}$, Fauzi Mulyatna ${ }^{2}$, Indra Martha Rusmana ${ }^{3}$ \\ ${ }^{1}$ Progam Studi Pendidikan Matematika, Universitas Indraprasta PGRI Jakarta \\ ${ }^{2}$ Progam Studi Pendidikan Matematika, Universitas Indraprasta PGRI Jakarta \\ ${ }^{3}$ Progam Studi Pendidikan Matematika, Universitas Indraprasta PGRI Jakarta \\ Corresponding author: \\ E-mail : arfatin.nurrahmah@unindra.ac.id
}

Diterima 2 Juli 2019, Disetujui 18 Juli 2019

\begin{abstract}
ABSTRAK
Kegiatan PKM Model Pembelajaran di Pondok Pesantren An-Nahl Darunnajah 5 Cikeusik, Pandeglang ini bertujuan untuk menjadikan guru sebagai pendidik yang berkualitas dan membawa suasana menyenangkan, dapat mengoptimalkan belajar peserta didik meningkatkan motivasi peserta didik menjadi lebih tinggi, sehingga mempunyai rasa senang dalam mengikuti proses pembelajaran. Kegiatan ini diharapkan mampu memberikan gambaran bagi guru mengenai model pembelajaran untuk mengembangkan dan mengoptimalkan kemampuan softskill peserta didik dalam kegiatan pembelajaran di Pondok Pesantren An Nahl Darunnajah 5. Peserta dalam kegiatan pelatihan ini adalah seluruh pengajar di Pondok Pesantren An-Nahl Darunnajah 5. Metode yang digunakan untuk mencapai tujuan yang telah dirumuskan di atas adalah memberikan informasi dalam penerapan Model Pembelajaran dengan Kombinasi Cooperative Learning. Materi yang diberikan saat pelatihan memuat pengenalan, perancangan dan penerapan. Pelaksanaan kegiatan ini dilakukan dalam tiga tahap, yaitu tahap persiapan, pelaksanaan, dan evaluasi.
\end{abstract}

Kata kunci: Model Pembelajaran

\begin{abstract}
PKM Activities Learning Model at Pondok Pesantren An-Nahl Darunnajah 5, Cikeusik, Pandeglang, Aims to make teachers a quality educator, and bring a pleasant atmosphere, can optimise student learning to increase the motivation of learners to a higher level, so have the pleasure of following the learning process. This activity is expected to provide a description for teachers on the model of learning to develop and optimize the ability of the student softskills in the learning activities at Pondok Pesantren An Nahl Darunnajah 5. Participants in this training activities are all teachers in Pondok Pesantren An-Nahl Darunnajah 5. The method used to achieve the above-formulated objectives is to provide information in the implementation of the learning Model with a combination of Cooperative Learning. The materials provided during the training contained the introduction, design and implementation. The implementation of this activity is conducted in three phases, namely the preparation, implementation, and evaluation.
\end{abstract}

Keywords: Learning Model

\section{PENDAHULUAN}

Pembelajaran di masa kini mempunyai tantangan besar untuk membekali peserta didik, tidak hanya ilmu pengetahuan yang berkualitas namun juga memiliki karakter yang baik. Pembentukan karakter tercipta dari proses belajar mengajar. Ada beberapa faktor yang mempengaruhi hasil pembelajaran seorang peserta didik. Baik buruknya hasil pembelajaran yang didapatkan oleh peserta didik tergantung pada proses yang mereka lalui. Jika proses dan faktor pendukung diberdayakan dengan baik, maka luaran pengetahuan, keterampilan dan sikap peserta didik pun juga akan sesuai dengan yang diharapkan. Namun, kebalikannya jika proses yang dialami oleh peseta didik tidak sejalan dengan yang diharapkan, luaran berupa pengetahuan, keterampilan dan sikap yang dimiliki peserta didik tidak baik. Sekolah yang merupakan salah satu faktor pendukung sebagai lingkungan belajar peserta didik, harus menjadi tempat dimana peserta didik dapat memberdayakan potensi siswa ke arah yang 
berkarakter. Sekolah sebagai tempat di mana diadakan proses pembelajaran, haruslah memfasilitasi peserta didik agar dapat berinteraksi dengan ligkungan sehingga proses pembelajaran berjalan optimal.

Pendidikan karakter sebenarnya sangat penting diterapkan dalam proses pembelajaran. Departemen Pendidikan Nasional sudah menginstruksikan kepada sekolah-sekolah untuk menanamkan beberapa karakter pembangun mental (character building) bagi peserta didik. Namun, apa yang diharapkan pemerintah belum berjalan semestinya. Hal ini disebabkan oleh beberapa hal, antara lain: Pertama, kurang terampilnya para guru menyelipkan pendidikan karakter dalam proses pembelajaran. Kedua, sekolah terlalu fokus mengejar target-target akademis, khususnya target lulus ujian nasional (UN). Karena sekolah masih fokus pada aspek-aspek kognitif (intelektual), baik nasional maupun lokal pada satuan pendidikan, maka aspek soft skills sebagai unsur utama pendidikan karakter justru diabaikan. Ketiga, banyaknya stakeholder pendidikan belum mampu memberikan contoh teladan terhadap anak didik. Keempat, era globalisasi yang sangat pesat menggemparkan membawa tantangan serius bagi dunia pendidikan (Sukri, 2013).

Menurut Muslich (2011) dalam pendidikan karakter di sekolah semua komponen (stakeholder) harus dilibatkan, termasuk komponen-komponen pendidikan itu sendiri, yaitu isi kurikulum, proses pembelajaran, kualitas hubungan, penanganan atau pengelolaan mata pelajaran, pengelolaan sekolah, pelaksanaan aktivitas atau kegiatan kurikuler, pemberdayaan sarana prasarana, pembiayaan, dan etos kerja seluruh warga dan lingkungan sekolah. Senada dengan lah itu, Peterson dan Deal (dalam Zuchdi, 2011) menyatakan bahwa masing-masing komponen sekolah memainkan peran yang berbedabeda. Berdasarkan hasil observasi yaitu melakukan wawancara dengan beberapa pengajar di lingkungan mitra, didapatkan kesimpulan bahwa: 1) Guru masih merasa kesulitan dalam mengintegrasikan pendidikan karakter dalam proses pembelajaran; 2) Pondok Pesantren masih terlalu fokus pada aspek kognitif (pengetahuan); 3) Era industri 4.0 dimana teknologi yang sangat pesat tantangan serius bagi dunia pendidikan dan mempengaruhi karakter peserta didik.

Peran guru sangatlah penting dalam pelaksanaan pendidikan karakter terhadap siswa, karena berinteraksi langsung secara terus menerus dalam proses pembelajaran.
Guru harus mempersiapkan berbagai pilihan dan strategi untuk menanamkan setiap nilainilai, norma-norma, dan kebiasaan-kebiasaan ke dalam setiap mata pelajaran yang diampunya. Guru merupakan model secara langsung bagi siswa, oleh karena itu guru harus memiliki sikap-sikap sebagai pendidik karakter. Di semua tingkatan, tujuan pendidikan adalah untuk melibatkan seluruh peserta didik dalam pembelajaran bermakna, yang dapat terjadi dalam proses belajar mengajar. Belajar merupakan proses mengalami sehingga dapat mengembangkan keterampilan yang sudah dimiliki dan membangun pengetahuan lebih lanjut. Di era teknologi ini, sudah terjadi pergeseran paradigma yang mengharuskan seorang pendidik untuk terus berupaya mengembangkan strategi dan metode pembelajaran yang efektif dan tepat sasaran, sehingga pembelajaran yang efektif dan bermakna dapat terwujud. Masalah pokok yang akan dipecahkan dalam pengabdian masyarakat ini berkaitan dengan masih minimnya informasi mengenai model pembelajaran untuk mengembangkan dan mengoptimalkan kemampuan softskill peserta didik dalam kegiatan pembelajaran di Pondok Pesantren An Nahl Darunnajah 5. Oleh karena itu, diperlukan berbagai model pembelajaran yang tepat dan relevan, salah satunya adalah model kombinasi pembelajaran kooperatif dengan pendekatan project based learning.

Untuk mengatasi permasalahan yang dihadapi oleh mitra yaitu Pondok Pesantren An-Nahl Darunnajah 5 Cikeusik, maka solusi yang ditawarkan antara lain: a) pelatihan model pembelajaran dengan kombinasi cooperative learning pendekatan project based learning untuk membangkitkan minat peserta didik b) Memfasilitasi kesempatan untuk meningkatkan inovasi pembelajaran guru dalam proses pembelajaran. Target lain yaitu tersedianya perangkat pembelajaran model pembelajaran dengan kombinasi cooperative learning pendekatan project based learning yang sudah disusun oleh guru.

\section{METODE}

Metode yang digunakan untuk mencapai tujuan yang telah dirumuskan di atas adalah memberikan informasi dalam penerapan Model Pembelajaran dengan Kombinasi Cooperative Learning. Materi yang diberikan saat workshop memuat pengenalan, perancangan dan penerapan. Pelaksanaan kegiatan ini dilakukan dalam tiga tahap, yaitu tahap persiapan, pelaksanaan, dan evaluasi. 
Tahap pertama adalah tahap persiapan. Dalam tahap ini tim melakukan survei pendahuluan untuk mengetahui kondisi target kegiatan dengan menganalisis kondisi tempat yang akan digunakan, kondisi peserta yang akan diberikan pelatihan, dan menyusun rancangan kegiatan yang akan dilakukan. Tahap kedua yaitu tahap pelaksanaan. Tim melakukan pelatihan Model Pembelajaran dengan Kombinasi Cooperative Learning sebagai Strategi Menjadikan Sekolah Berkarakter yang ditujukan untuk seluruh perangkat Pondok Pesantren An Nahl Darunnajah 5. Tahap ketiga adalah evaluasi. Evaluasi kegiatan ini dilakukan terhadap proses kegiatan. Evaluasi berkaitan selama kegiatan berlangsung dari tahap persiapan sampai tahap pelaksanaan, yang meliputi keadaan sekolah, kehadiran peserta pelatihan, antusias peserta saat mengikuti kegiatan, dan saran atau kritik terhadap kegiatan.

Waktu pelaksanaan kegiatan selama bulan Maret hingga Agustus tahun 2019, mulai dari observasi daerah mitra hingga pembuatan laporan. Kegiatan pelatihan ini akan dilaksanakan di Pondok Pesantren An Nahl Darunnajah 5, yang beralamat di Jl. Cikareo Mantiung, Ciseureuh, Tanjungan, Pandeglang, Banten, Jawa Barat. Kegiatan ini akan dilaksanakan pada bulan Mei 2019. Adapun partisipasi mitra dalam hal ini adalah pihak Pondok Pesantren An-Nahl Darunnajah 5 dalam kegiatan pengabdian kepada masyarakat antara lain: 1) Partisipasi dalam perencanaan dan pengambilan keputusan.; 2) Partisipasi dalam pelaksanaan, meliputi: penyediaan tempat, sumber daya dana, kegiatan administrasi, koordinasi dan penjabaran program. Partisipasi dalam pelaksanaan merupakan kelanjutan dalam rencana yang telah digagas sebelumnya baik yang berkaitan dengan perencanaan, pelaksanaan maupun tujuan.; 3) Partisipasi dalam evaluasi. Partipasi dalam evaluasi ini berkaitan dengan pelaksanaan program yang sudah direncanakan sebelumnya.

\section{HASIL DAN PEMBAHASAN} Hasil

Sesuai dengan skema yang sudah direncanakan oleh tim abdimas, pelaksanaan kegiatan ini dilakukan dalam tiga tahap, yaitu tahap persiapan, pelaksanaan, dan evaluasi. Realisasi pelaksanaan sesuai dengan perencanaan tim pelaksana. Pada tahap persiapan, tim pelaksana meninjau lokasi mitra yaitu Pondok Pesantren An-Nahl Darunnajah 5. Pondok Pesantren An Nahl Adalah Salah
Satu Cabang Pesantren Darunnajah Jakarta yang ke 5 dengan Luas areal 2 hektar. Pondok Pesantren An Nahl didirikan Pada tanggal 18 Juli 2004 yang tempatnya berada di ujung barat pulau Jawa, tepatnya di Kampung Ciseureuh Desa Tanjungan Kecamatan Cikeusik Kabupaten Pandeglang Provinsi Banten.

Pondok pesantren Darunnajah 5 AnNahl terdiri dari Madrasah Aliyah, Madrasah Tsanawiyah dan Madrasah Ibtidaiyah. Visi dari Ponpes ini adalah menuju pesantren mandiri sebagai sentral pembinaan generasi tafaqquhfiddindan kaderasasi pemimpin umat. Dalam kegiatan survey lokasi objek penelitian ini dilakukan diskusi dengan pimpinan pesantren, kepala sekolah dan beberapa guru untuk mengetahui permasalahan mitra yang terjadi. Dari hasil diskusi tersebut, didapatkan bahwa permasalahan yang dihadapi guru adalah: 1) Guru masih merasa kesulitan dalam mengintegrasikan pendidikan karakter dalam proses pembelajaran, 2) Sekolah masih terlalu fokus pada aspek kognitif (pengetahuan), 3) tuntutan di Era industri 4.0 dimana teknologi yang sangat pesat tantangan serius bagi dunia pendidikan dan mempengaruhi karakter peserta didik.

Berdasarkan masalah tersebut, tim pengabdian dan pihak pondok pesantren sepakat mengadakan kegiatan pengabdian masyarakat untuk meningkatkan kompetensi guru melalui pelatihan yang bertujuan menjadikan guru sebagai pendidik yang berkualitas dan membawa suasana menyenangkan di setiap proses pembelajaran. Adapun pelatihan yang diberikan meliputi materi : model Pembelajaran Kooperatif dengan pendekatan Project Based Learning, Pembelajaran Matematika yang mengasikkan, dan pemberian motivasi kepada guru di lingkungan pondok pesantren An-Nahl 5 Darunnajah. Sesuai dengan kesepakatan yang dilakukan antara tim abdimas dan pihak pondok pesantren, maka pelaksanaan kegiatan abdimas dilakukan pada selama dua hari.

Pada hari pertama, pukul 07.00 tim berkumpul di Kampus A Universitas Indraprasta PGRI untuk menuju lokasi pengabdian. Karena jarak tempuh yang lumayan jauh, maka tim sudah menyiapkan segala perbekalan selama dalam perjalanan. Tim tiba di lokasi pada pukul 16.00. Tim diarahkan untuk beristirahat di tempat yang sudah disediakan oleh pihak pondok pesantren. Sehabis solat isya, tim dan pihak pondok pesantren yang diwakili oleh pimpinan pondok 
dan salah satu pengajar Pondok yaitu mendiskusikan mengenai persiapan pelaksanaan kegiatan abdimas yang akan dilaksanakan esok hari.

Keesokan hari, kegiatan dimulai pukul 08.00 dengan pemberian sambutan yang disampaikan oleh Pimpinan pondok pesantren An-Nahl 5 Darunnajah, Cikeusik, Pandeglang, Banten, sekaligus membuka kegiatan Pengabdian Kepada Masyarakat. Berikutnya adalah sambutan dari Ketua Tim Pelaksana Abdimas. Peserta kegiatan terdiri dari seluruh pengajar di lingkungan Pondok Pesantren AnNahl 5 Darunnajah, Cikeusik, Pandeglang.

Pemberian materi dilaksanakan secara bergantian. Pelatihan pertama mengenai materi Pelatihan Model Pembelajaran Project Based Learning dimulai pukul 08.30. Materi berlangsung selama 90 menit dan guru terlihat antusias mengikuti materi. Pemateri pertama menyajikan Model Pembelajaran Project Based Learning dengan mengaitkan pembelajaran pada kurikulum 2013. Peserta didik dianggap telah memiliki pengetahuan awal yang nanti akan digali kreativitasnya oleh guru.

Guru dituntut aktif agar dapat menumbuhkan kreatifitas peserta didik sehingga aktif dalam pembelajaran. Contohnya dengan menampilkan permasalahan sehari-hari yang terjadi di lingkungan sekitar, misal mengukur daundaunan yang ada di sekitar peserta didik. Dari data yang sudah terkumpul, dapat dihubungkan dengan kajian materi yang akan dibahas. Daun-daun yang sudah dikumpulkan dapat dicari ukurannya untuk mencari data kelompok, dan seterusnya.

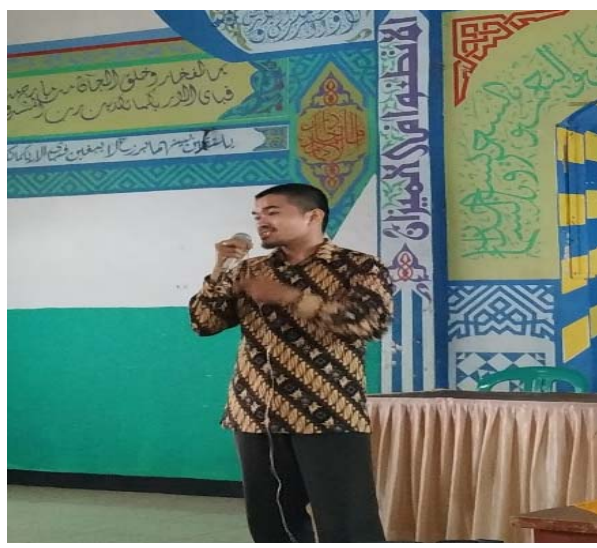

Gambar 1. Penyampaian materi PKM
Peserta terlihat tertarik dan antusias dengan materi yang disampaikan oleh tim, terlihat dengan keaktifan dalam bertanya. Salah satu peserta menanyakan kondisi yang terjadi sehari-hari di kelas mengenai bagaimana untuk mengatur peserta didik agar tidak ribut saat proses pembelajaran project based learning ini diterapkan. Tim memberikan solusi bahwa dengan diterapkannya pembelajaran project based learning ini maka peserta didik akan terlibat aktif sehingga tidak ada kesempatan untuk melakukan aktivitas lain selain belajar. Pertanyaan selanjutnya ialah langkah-langkah yang harus dilakukan agar pembelajaran berbasis proyek sukses dilakukan. Tim memberikan solusi yaitu kata kunci pembelajaran berbasis proyek adalah adanya produk. Langkah-langkah yang dilakukan adalah guru merancang terlebih dahulu proyek apa yang harus dikerjakan oleh peserta didik, apa saja yang harus disiapkan oleh peserta didik, kemudian waktu yang tepat untuk dilaksanakan dan kapan peserta didik harus mengumpulkan proyek yang sudah ditugaskan.

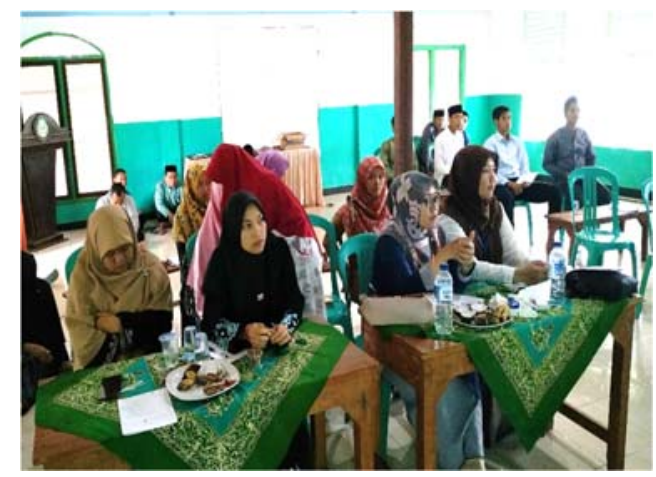

Gambar 2. Peserta menyimak penjelasan tim

Materi selanjutnya dimulai pukul 10.00 mengenai Kombinasi pembelajaran Kooperatif. Materi disampaikan selama 90 menit hingga pukul 11.30. Beberapa materi model pembelajaran kombinasi cooperative learning antara lain STAD (Student TeamsAchievement Division), JIGSAW, TAI (Team Assisted Individualization), TGT (Teams Games Tournaments). Setelah materi disampaikan, guru dipersilahkan untuk mencoba membuat rancangan pembelajaran dengan menggunakan model pembelajaran kombinasi cooperative learning menggunakan pendekatan yang akan dilakukan dengan didampingi oleh tim PKM. 


\section{Pembahasan}

Seorang guru memiliki tanggungjawab besar dalam mengelola pembelajaran yang berkualitas. Salah satu upaya yang dilakukan untuk meningkatkan kinerja maupun keprofesionalismean guru melalui berbagai pelatihan dan pembinaan, seperti yang dilakukan oleh tim pengabdian masyarakat yaitu PKM di Pondok Pesantren Darunnajah 5 Cikeusik. Adapun pelatihan yang diberikan meliputi materi : model kombinasi pembelajaran kooperatif dengan pendekatan project based learning. Dalam pendekatan Project based learning, peserta didik diberikan kebebasan untuk merencanakan kegiatan pembelajaran, melaksanakan proyek secara kolaboratif hingga akhirnya dapat menghasilkan produk untuk dipresentasikan. Pendekatan Project Based Learning diawali dengan menyajikan permasalahan nyata di sekitar peserta didik, dan peserta didik dibimbing untuk menyelesaikan permasalahan tersebut melalui pembuatan proyek sederhana dan bermakna. Hal ini dilakukan agar peserta didik dapat lebih mudah dalam memahami suatu konsep dalam pembelajaran matematika, sehingga diharapkan adanya peningkatan hasil belajar dari peserta didik. Permasalahan yang diangkat dapat diambil dari lingkungan sehari hari yang dialami oleh peserta didik. Sebagai contoh, dalam materi pengukuran, guru dapat menyiapkan alat ukur dengan bahan-bahan yang ada di lingkungan sekitar, seperti: penggaris, pulpen atau spidol, sedotan, dan bahan lain yang dapat digunakan untuk mengukur panjang.

Contoh lain, materi bangun datar dan bangun ruang. Peserta didik dapat diminta untuk mengamati segala benda yang ada disekitarnya dan menyebutkan benda tersebut termasuk ke dalam bangun ruang yang mana, guru hanya memberitahukan ciri-ciri dari bangun ruang tersebut. Misalnya atap rumah atau sekolah yang berbentuk limas segi empat, papan tulis yang berbentuk persegi panjang, tempat kapur atau tempat spidol yang berbentuk balok, dan sebagainya. Saat mengamati dan menelaah masalah yang ada, peserta didik diharapkan dapat mengintegarsikan pengetahuan baru berdasarkan pengetahuan awal maupun pengalaman nyata yang dimilikinya. Menurut Solekhah, dkk pembelajaran berbasis proyek ini selalu mengikutsertakan peserta didik agar terlibat aktif dalam pembelajaran pengetahuan sikap maupun dalam bentuk proyek.

Pembelajaran di SD yang menerapkan pendekatan tematik dan pendekatan scientific perlu didukung dengan pendekatan lain seperti pendekatan berbasis proyek dan dikombinasikan dengan model pembelajaran kooperatif. Berdasarkan permasalahan yang dialami oleh guru, sebagian besar guru masih kesulitan dalam mengaplikasikan pendekatan pembelajaran pada perangkat yang sudah mereka siapkan. Guru sudah mengenal apa itu pendekatan PJBL atau model pembelajaran kooperatif, namun belum memahami langkahlangkah dalam menerapkannya di kelas. Umumnya guru masih mengembangkan pembelajaran sesuai dengan RPP baku yang sudah mereka buat sebelumnya.

Tahap selanjutnya, peserta diberikan contoh mengeni perangkat pembelajaran yang menerapkan model pembelajaran kooperatif dengan pendekatan pembelajaran berbasis proyek. Peserta terlihat antusias menyimak dan melakukan tanya jawab mengenai cointoh perangkat pembelajaran yang ditampilkan. Selanjutnya peserta diminta oleh tim pengabdian untuk membentuk kelompok untuk dapat mensimulasikan kegiatan pembelajaran yang menggunakan model pembelajaran kooperatif dengan pendekatan berbasis proyek. Setelah itu diadakan sesi diskusi dan peserta memberikan tanggapannya terkait kegiatan yang sudah dilakukan, baik berupa kelebihan dan kekurangan dari kegiatan pengabdian kepada masyarakat ini.

Berdasarkan diskusi dengan guru, maka keuntungan yang didapatkan jika menerapkan pembelajaran kooperatif dengan pendekatan project based learning antara lain: a) Dapat meningkatkan motivasi belajar peserta didik, b) meningkatkan kemampuan pemecahan masalah dan komunikasi peserta didik, c) meningkatkan kerja sama peserta didik dalam kelompok, d) meningkatkan keterampilan mengelola sumber. Dengan adanya kegiatan seperti ini maka mereka dapat lebih mengetahui pembelajaran seperti apa yang dapat meningkatkan keaktifan dan motivasi peserta didik dalam belajar. Penerapan pembelajaran kooperatif dirasakan cocok untuk diterapkan di kelas karena adanya interaksi yang positif antar peserta didik dan karakter peserta didik menjadi lebih baik. Interaksi terjadi ketika peserta didik berkelompok dalam pembelajaran kooperatif bertujuan untuk mengembangkan keterampilan sosial, komunikasi sehingga akan berdampak positif terhadap karakter peserta didik. Hal ini sesuai dengan pendapat Zubaedi (dalam Farhan, dkk, 2017) yang menyatakan bahwa interaksi kelompok dalam pembelajaran kooperatif bertujuan mengembangkan 
keterampilan sosial dan berdampak positif diantaranya adalah kerjasama, berkomunikasi, kedisplinan, tanggungjawab, kejujuran, kolaboratif serta solidaritas.

Terlebih jika mereka menerapkan pembelajaran berbasis proyek, karena guru dapat meminta peserta didik memanfaatkan alam sekitar dan mengangkat menjadi permasalahan yang dapat digunakan sebagai materi pelajaran. Dalam pembelajaran berbasis proyek, peserta didik didorong lebih aktif dan saling bekerjasama dalam kelompok belajar. Peran guru hanya sebagai fasilitator dan evaluator yang mengevaluasi produk hasil pekerjaan peserta didik. Hal Ini sesuai dengan pendapat Husna, dkk (2016) yang menyatakan bahwa dengan mengimplementasikan model project based learning, kemampuan komunikasi matematis peserta didik dapat semakin meningkat dengan cara pemberian tugas-tugas proyek yang menuntut peserta didik untuk bisa mengkomunikasikan ide matematis berdasarkan temuan-temuan mereka selama melakukan tugas-tugas proyek baik secara lisan maupun tertulis.

\section{SIMPULAN DAN SARAN}

Secara umum kegiatan pengabdian masyarakat ini dirasa telah berjalan dengan baik dan memberi kontribusi positif sebagai upaya untuk menciptakan pendidikan yang berkualias. Kegiatan ini telah berjalan dengan baik dan dapat disimpulkan sebagai berikut: 1) PKM dengan penerapan model pembelajaran kooperatif dengan pendekatan Project based learning merupakan suatu pendekatan yang dapat meningkatkan keaktifan dan motivasi peserta didik dalam belajar; 2) Materi penerapan pembelajaran matematika yang mengasikkan bertujuan untuk mengoptimalkan belajar peserta didik meningkatkan motivasi peserta didik menjadi lebih tinggi, sehingga mempunyai rasa senang dalam mengikuti proses pembelajaran.

Dari simpulan di atas, maka kami mengajukan saran dan rekomendasi sebagai berikut: 1) Hendaknya peserta didik dapat berpartisipasi aktif dalam proses pembelajaran agar lebih mudah untuk mengerti, memahami dan menerapkan ilmu pengetahuannya di kehidupan sehari-hari.; 2) Guru hendaknya selalu mengamati perilaku peserta didik selama proses pembejaran agar dapat membantu guru memahami setiap permasalahan yang dihadapi peserta didik; 3) Untuk kegiatan selanjutnya, diharapkan dapat mengembangkan model pembelajaran kooperatif dengan pendekatan yang lebih inovatif untuk meningkatkan karakter dan hasil belajar peserta didik.

\section{DAFTAR RUJUKAN}

Farhan, Sabiq, dkk. "Pengaruh Penerapan Pendidikan Karakter Melalui Model Pembelajaran Student Team Achievement Division Terhadap Hasil Belajar Pemeliharaan Mesin Kendaraan Ringan Smk Pancasila Surakarta",JIPTEK, Vol X, No. 2, h. 47-55, Juli 2017.

Husna, Nurul, dkk. "Implementasi Model Project Based Learning Untuk Meningkatkan Kemampuan Komunikasi Matematis Siswa",JPMI, Vol 1, No. 1, h. 39-43, Maret 2016.

Muslich, Masnur. 2011. Pendidikan Karakter: Menjawab Tantangan Krisis Multidimensional. Jakarta: Bumi Aksara.

Sukri. 2013. "Implementasi Pendidikan Karakter di Sekolah Menengah Pertama Islam Terpadu (SMPIT) Darul Azhar Aceh Tenggara". Tesis. IAIN Sumatera Utara.

Zuchdi, Darmiyati. 2011. Pendidikan Karakter dalam Perspektif Teori dan Praktik.rev.ed. Yogyakarta: UNY Press 